\title{
Analysis of the error associated with the subsampling of Chironomidae in an intermittent stream of semi-arid Brazil
}

\author{
Rafaela Lima de Farias ${ }^{1}$, Thuanny Fernanda Braga Alencar ${ }^{I}$, Jéssica Alcoforado de Sena Lima ${ }^{I}$ \\ \& Elvio Sergio Figueredo Medeiros ${ }^{1,2}$ \\ ${ }^{1}$ Grupo de Ecologia de Rios do Semiárido, Universidade Estadual da Paraíba, João Pessoa, PB, Brazil. \\ ${ }^{2}$ Corresponding author: Elvio S.F.Medeiros, e-mail: elviomedeiros@uepb.edu.br
}

FARIAS, R.L., ALENCAR, T.F.B., LIMA, J.A.S., MEDEIROS, E.S.F. Analysis of the error associated with the subsampling of Chironomidae in an intermittent stream of semi-arid Brazil. Biota Neotropica. 15(1): e20140039. http://dx.doi.org/10.1590/1676-06032015003914

\begin{abstract}
Chironomidae is a common family in freshwaters, often occurring at high densities, which hinders the processing of large samples, given that time and labor are usually limited. The present study aims at evaluating the extent of the error related with the subsampling of Chironomidae from a larger sample with regard to the size of the individuals between a sample and the subsample. A total of 9195 chironomids were collected from three sites in an intermittent stream. Samples were taken using a Dshaped net $(250 \mu \mathrm{m})$ on eight occasions. Individuals from each sample were homogenized in a gridded Petri dish and coordinates from lines and columns were randomly drawn. Individuals from the assigned coordinates were selected until 100 individuals or $10 \%$ of the sample were chosen. Comparisons were made between the proportion of larger $(\geq 5 \mathrm{~mm})$ and smaller individuals $(<5 \mathrm{~mm})$ between the samples and subsamples, and it was established the correlation between the size of the error and the size of the sample, using the rank coefficient of Spearman. The highest error observed was $12.7 \%$, meaning that the difference in larger individuals between the sample and subsample reached that value. However on six of the eight samples the error was below 3\%. Spearman correlation showed no significance between the error observed and the size of the sample $(\rho=0.38, p=0.35)$, meaning that larger samples will not yield larger error associated with the size of the individuals. The present study indicates that the subsampling technique used is capable of drawing a random subset of individuals from a sample of chironomids with regard to their size. This technique can be used in ecological or biomonitoring studies in order to reduce sample processing time without creating a bias in the analysis.
\end{abstract}

Keywords: temporary pools, sampling effort, aquatic insects.

FARIAS, R.L., ALENCAR, T.F.B., LIMA, J.A.S., MEDEIROS, E.S.F. Análise do erro associado com a subamostragem de Chironomidae em um rio intermitente do semiárido do Brasil. Biota Neotropica. 15(1): e20140039. http://dx.doi.org/10.1590/1676-06032015003914

Resumo: Chironomidae é uma família comum em águas doces, frequentemente ocorrendo em altas densidades, o que dificulta o processamento de amostras para estudos ecológicos, dado que o tempo e recursos são geralmente limitados. O presente estudo tem como objetivo avaliar a dimensão do erro relacionado com a subamostragem de Chironomidae em relação ao tamanho de indivíduos entre a amostra e a subamostra. Um total de 9195 quironomídeos foi coletado de três sítios em um rio intermitente. As amostras foram tomadas usando uma rede tipo D $(250 \mu \mathrm{m})$ em oito ocasiões. Os indivíduos de cada amostra foram homogeneizados em uma placa de Petri quadriculada e as coordenadas de linhas e colunas foram sorteadas. Indivíduos das coordenadas atribuídas foram selecionados até que 100 indivíduos ou $10 \%$ da amostra fossem escolhidos. Comparações foram feitas entre a proporção de indivíduos grandes $(\geq 5 \mathrm{~mm})$ e pequenos $(<5 \mathrm{~mm})$ entre amostras e subamostras e foi estabelecida a correlação entre o tamanho do erro e o tamanho da amostra, utilizando o coeficiente por rank de Spearman. A maior diferença de indivíduos grandes entre amostra e subamostra (erro) foi de 12,7\%. No entanto, em seis das oito amostras o erro foi inferior a 3\%. Correlação de Spearman não mostrou significância entre o erro observado e o tamanho da amostra $(\rho=0,38 ; p=0,35)$, o que significa que amostras maiores não produziram maior erro relacionado com o tamanho dos indivíduos. $\mathrm{O}$ presente estudo indica que a técnica de subamostragem utilizada é capaz de extrair um subconjunto aleatório de tamanho de indivíduos a partir de uma amostra de Chironomidae. Essa técnica pode ser usada em estudos ecológicos ou de biomonitoramento a fim de reduzir o tempo de processamento das amostras sem criar um viés na análise.

Palavras-chave: poças temporárias, esforço amostral, insetos aquáticos. 


\section{Introduction}

The Chironomidae family is a common taxon in freshwaters, frequently occurring in high densities and richness in several aquatic environments including Brazilian semi-arid streams (Trivinho-Strixino 2011, Rocha et al. 2012, Carvalho et al. 2013). These organisms are important colonizers of the sediment and aquatic vegetation, contributing with the breakdown of organic matter. They have a wide range of survival mechanisms, being either physiological/morphological or behavioral, which enables their existence in unfavorable conditions of temperature, $\mathrm{pH}$, salinity and dissolved oxygen (Weber 1980). These characteristics make the Chironomidae family an important indicator for the environmental conditions, being used as a tool in biomonitoring studies (Rosenberg 1998).

The identification of their aquatic larval stage is made through the preparation of semipermanent slides for the observation of characters mostly in their head (TrivinhoStrixino 2011). Only then, individuals can be counted and the data used for ecological studies of community structure (Farias et al. 2012). This process is both labor and time-consuming, which often makes the counting of all individuals an unrealistic demand for laboratory work. Even though this has been argued to be the most appropriate approach to studies with benthic invertebrates (Baker \& Huggins 2005), resource limitation and individuals numbers reaching the thousands often demand the subsampling of larger samples (Courtemanch 1996, Baker \& Huggins 2005, Anderson \& Ferrington 2012 ).

The basic advantages of subsampling is the reduction in effort on counting and identifying individuals which enables processing a greater number of samples. The latter is especially important in intermittent streams, because they require to incorporate both temporal and spatial natural variation. Furthermore, in unequal sample sizes, subsampling may be used as a way of correcting for the sample size and at the same time understand a larger portion of the variation in the community (Sebastien et al. 1988, King \& Richardson 2002, Baker \& Huggins 2005, Bouchard \& Ferrington 2011).

Associated with unequal sample sizes, chironomids themselves present diverse morphotypes (Trivinho-Strixino 2011) leading to different individuals sizes. Subsampling techniques applied to individuals after sorting can create bias in the subsample since larger individuals or morphotypes will tend to be more readily picked than smaller ones. To enable unbiased randomization, individuals must be numbered and these numbers randomly drawn. In large samples with thousands of organisms this is unfeasible. Therefore we propose an alternative method where one spreads individuals in a gridded Petri dish and randomly draw coordinates (lines and columns) in order to sort individuals. Since larger individuals will occupy more squares in the grid, and thus have a greater chance of being selected, a test for the size of this bias is necessary. Therefore, the present study (1) quantifies the existence and proportion of the error related with chironomid size between a sample and its subsample and (2) determines if this error increases in larger samples.

\section{Material and Methods}

Chironomids were collected from three different sites on the Ipanema River, an intermittent river in semi-arid Brazil. Two sites were collected three times (April, July and October 2007) and one site was collected twice (April and July 2007) (Table 1). At each sampling, the sediment was taken using a D-shaped net (40 $\mathrm{cm}$ wide and $250 \mu \mathrm{m}$ mesh). Since water flow was nil or low, the net was dragged for $40 \mathrm{~cm}$ at a depth of $2.5 \mathrm{~cm}$ (representing a volume of $40 \times 40 \times 2.5 \mathrm{~cm}$ ). The depth of the sample was approximate, based on a measuring rod attached to the frame of the net. Three drags were performed for each sampling occasion and these were later pooled together and are henceforth referred to as a "sample". Thus, a total of 8 samples were used in the present study. Samples were fixed in $4 \%$ formalin in the field and taken to the laboratory where they were preserved in $70 \%$ alcohol. Since sampling in the present study was performed at different sites and occasions, the number of individuals varied for each sample (see Table 1). This natural variation was used to test for the correlation between the size of the error and the size of the sample.

At the laboratory, all Chironomidae on each sample were sorted and counted before proceeding to subsampling. Subsampling was adapted from the fixed fraction and fixed count methods (Baker \& Huggins 2005). The chironomid of a sample was homogenized on a gridded Petri dish with each square measuring $1 \times 1 \mathrm{~mm}$. Each column and line of the grid was numbered and then line and column numbers were randomly drawn. Individuals from the assigned $1 \mathrm{~mm}^{2}$ coordinates were selected. This process was repeated until approximately $10 \%$ of the individuals of the sample were chosen; these represent a subsample. Samples with less than 1000 individuals had approximately 100 individuals randomly sorted. We refer to this technique as an a posteriori subsampling. That is, not taking a subsample of the sediment collected and then identifying all chironomids in that subsample, but instead, sorting all chironomids from the sample and then taking a subsample of the individuals for identification.

Comparisons were made between the proportion of larger ( $\geq 5 \mathrm{~mm}$ ) and smaller individuals $(<5 \mathrm{~mm})$ between the samples and subsamples. These size classes were based on preliminary analysis to identify larger larvae morphotypes (e.g. Chironomus, Dicrotendipes, Coelotanypus and Ablabesmyia) in comparison with smaller ones (e.g. Lauterborniella and Saetheria) for the study area.

It was established the correlation between the size of the error (difference in proportion of larger individuals between sample and subsample) and the size of the sample, using the rank coefficient of Spearman $(\alpha=0.05)$ (Sheridan \& Lyndall 2001).

\section{Results and Discussion}

A total of 9195 individuals were collected from the eight study sites (Table 1). The highest difference in larger individuals between the sample and the subsample was $12.7 \%$ (Site 1 April). However, on six of the eight samples this error was below $3 \%$. The lowest variation was observed at the Site 3 in October, where $1.3 \%$ of the chironomids in the sample were larger than $5 \mathrm{~mm}$ and this value for the subsample was $1.8 \%$, showing a difference of only $0.5 \%$. Spearman correlation showed no significance between the error observed and the size of the sample $(\rho=0.38, p=0.35)$, meaning that larger samples will not yield larger error associated with the size of the individuals.

Ideally, subsampling should reduce laboratory work and yield nonbiased and representative data, in order to reliably 
Subsampling of Chironomidae in the semi-arid

Table 1. Proportional difference in individuals between the sample and subsample (\%) for larger $(\geqslant 5 \mathrm{~mm})$ and smaller $(<5 \mathrm{~mm})$ Chironomidae in three sites from an intermittent river of semi-arid Brazil.

\begin{tabular}{|c|c|c|c|c|c|}
\hline \multirow[b]{2}{*}{ Sites } & \multicolumn{2}{|c|}{ Sample size } & \multicolumn{2}{|c|}{ Subsample size } & \multirow{2}{*}{$\begin{array}{l}\text { Difference in individuals } \\
\text { between the sample and } \\
\text { subsample (\%) }\end{array}$} \\
\hline & $<5 \mathrm{~mm}$ & $\geq 5 \mathrm{~mm}$ & $<\mathbf{5 m m}$ & $\geq \mathbf{5 m m}$ & \\
\hline \multicolumn{6}{|c|}{ Site 1 April } \\
\hline $\mathrm{N}$ & 986 & 53 & 134 & 29 & \\
\hline$\%$ & 94.9 & 5.1 & 82.2 & 17.8 & 12.7 \\
\hline \multicolumn{6}{|c|}{ Site 1 July } \\
\hline $\mathrm{N}$ & 518 & 59 & 120 & 15 & \\
\hline$\%$ & 89.8 & 10.2 & 88.9 & 11.1 & 0.9 \\
\hline \multicolumn{6}{|c|}{ Site 1 October } \\
\hline $\mathrm{N}$ & 1476 & 63 & 359 & 27 & \\
\hline$\%$ & 95.9 & 4.1 & 93.0 & 7.0 & 2.9 \\
\hline \multicolumn{6}{|c|}{ Site 2 April } \\
\hline $\mathrm{N}$ & 584 & 26 & 110 & 7 & \\
\hline$\%$ & 95.7 & 4.3 & 94.0 & 6.0 & 1.7 \\
\hline \multicolumn{6}{|c|}{ Site 2 July } \\
\hline $\mathrm{N}$ & 614 & 16 & 66 & 3 & \\
\hline$\%$ & 97.5 & 2.5 & 95.7 & 4.3 & 1.8 \\
\hline \multicolumn{6}{|c|}{ Site 3 April } \\
\hline $\mathrm{N}$ & 2486 & 54 & 259 & 23 & \\
\hline$\%$ & 97.9 & 2.1 & 91.8 & 8.2 & 6.1 \\
\hline \multicolumn{6}{|c|}{ Site 3 July } \\
\hline $\mathrm{N}$ & 766 & 4 & 84 & 1 & \\
\hline$\%$ & 99.5 & 0.5 & 98.8 & 1.2 & 0.7 \\
\hline \multicolumn{6}{|c|}{ Site 3 October } \\
\hline $\mathrm{N}$ & 1470 & 20 & 162 & 3 & \\
\hline$\%$ & 98.7 & 1.3 & 98.2 & 1.8 & 0.5 \\
\hline
\end{tabular}

represent the community being studied (Wrona et al. 1982, Barbour \& Gerritsen 1996). In the present study, we tested mostly the error related to chironomid size, from the sample to the subsample. We assume that an a posteriori subsampling would have as major drawback the tendency to select larger more easily viewed individuals, resulting from the fact that they occupy a larger area than smaller individuals. A clear advantage, however, is that the researcher has the number of the individuals sorted from the sample and can "return" to that if subsampling produce spurious results. More importantly, the total $\mathrm{N}$ of the sample is available for the researcher which in itself is an important information on the efficacy of the data generated by the subsampling procedure. In smaller samples, say up to 1000 individuals, all individuals may be counted and identified, but in larger samples (see Carvalho et al. 2013 and the present study), subsampling a proportion of the total number will increase overall sampling effort but also efficiency of the subsample as number of individuals increase. This is shown in the present study by the low difference in chironomid size between the sample and the subsample and by the lack of correlation between chironomid size related error and the size of the sample.

We showed in the present study that the subsampling technique used is capable of drawing a randomized subset of individuals from a sample of chironomids. This indicates that the technique tested for a posteriori sorting of individuals from a sample has the same probability of collecting larger or smaller individuals when compared with the original method of collection (in this case the D-shaped net). That means that larger individuals (or morphotypes) are not overestimated in relation to smaller ones, and that this is achieved regardless of the number of individuals in a sample.

Not surprisingly, in recent years a growing number of research groups have been implementing subsampling methods in their collection protocols (Carter \& Resh 2001, McCord et al. 2007, Petkovska \& Urbanic 2010, Anderson \& Ferrington 2012). However, it is important to ensure that such subsampling methods are representative of the sample and the study area, and that they are being interpreted bearing in mind the limitations of the subsampling technique (Farias et al. 2012, Ligeiro et al. 2012). In the Brazilian semi-arid streams, larger morphotypes are represented mostly by Chironomus, Dicrotendipes and Clinotanypus (e.g. Farias et al. 2012, Rocha et al. 2012). Nonetheless, other systems report other types of chironomids and consequently different larger morphotypes, such as Cryptochironomus, Axarus and Alotanypus (e.g. Stenert et al. 2012, Floss et al. 2012, Molozzi et al. 2011). Thus, even though the technique used in this study is of general application, it is important to perform pilot studies before the actual sampling and subsampling in order to understand the composition of the chironomid fauna and adjust the cut off value between large and small morphotypes in accordance with the local fauna.

We suggest the utilization of a posteriori subsampling in the laboratory in studies with large sample sizes collected from spatially and/or temporally variable aquatic systems, but emphasize the need for assessing the degree of randomness in the subsampling technique used and estimation of the error involved. 


\section{Acknowledgments}

Rafaela Farias is grateful to "Programa de Iniciação Científica UEPB/CNPq" for scholarship granted (PIBIC/ CNPq/UEPB 2008-2009). This research was supported by funds from Edital MCT/CNPq 02/2006 - Universal, Proc. 477545/ 2006-8. Elvio Medeiros holds a Brazilian Research Council (CNPq) Research Productivity Grant (312028/2012-1).

\section{References}

ANDERSON, A.M. \& FERRINGTON, L.C. 2012. Time-Efficiency of Sorting Chironomidae Surface-Floating Pupal Exuviae Samples from Urban Trout Streams in Northeast Minnesota, USA. Proceedings of the 18th International Symposium on Chironomidae-Fauna norvegica, 31:19-23.

BAKER, D.S. \& HUGGINS, D.G. 2005. Sub-sampling techniques for macroinvertebrates, fish and benthic algae sample in biological monitoring of streams and river. Relatório $\mathrm{n}^{\circ}$ 132. Kansas Biological Survey Lawrence.

BARBOUR, M.T. \& GERRITSEN, J. 1996. Subsampling of benthic samples: a defense of the fixed-count method. J. N. Am. Benthol. Soc. 15:386-391, http://dx.doi.org/10.2307/1467285

BOUCHARD, R.W. \& FERRINGTON, L.C. 2011. The effects of subsampling and sampling frequency on the use of surface-floating pupal exuviae to measure Chironomidae (Diptera) communities in wadeable temperate streams. Environ. Monit. Assess. 181(1-4):205233, http://dx.doi.org/10.1007/s10661-010-1824-6

CARTER, J.L. \& RESH, V.H. 2001. After site selection and before data analysis: sampling, sorting, and laboratory procedures used in stream benthic macroinvertebrate monitoring programs by USA state agencies. J. N. Am. Benthol. Soc. 20:658-682, http:// dx.doi.org/10.2307/1468095

CARVALHO, L.K., FARIAS, R.L. \& MEDEIROS, E.S.F. 2013. Benthic invertebrates and the habitat structure in an intermittent river of the semi-arid region of Brazil. Neot. Biol. Cons. 8(2):57-67.

COURTEMANCH, D.L. 1996. Commentary on the subsampling procedures used for rapid bioassessments. J. N. Am. Benthol. Soc. 15:381-385, http://dx.doi.org/10.2307/1467284

FARIAS, R.L., CARVALHO, L.K. \& MEDEIROS, E.S.F. 2012. Distribution of Chironomidae in a Semiarid Intermittent River of Brazil. Neot. Entomol. 41:450-460, http://dx.doi.org/10.1007/ s13744-012-0070-8

FLOSS, E.C.S., KOTZIAN, C.B., SPIES, M.R. \& SECRETTI, E. 2012. Diversity of Non-Biting Midge Larvae Assemblages in the Jacuí River Basin, Brazil. J Insect Sci. 12(121):1-33, http://dx.doi.org/ $10.1673 / 031.012 .12101$
KING, R.S. \& RICHARDSON, C.J. 2002. Evaluating subsampling approaches and macroinvertebrate taxonomic resolution for wetland biassessment. J. N. Am. Benthol. Soc. 21(1):150-171, http:// dx.doi.org/10.2307/1468306

LIGEIRO, R., FERREIRA, W., HUGHES, R.M. \& CALLISTO, M. 2012. The problem of using fixed-area subsampling methods to estimate macroinvertebrate richness: a case study with Neotropical stream data. Environ. Monit. Assess. 185(5):4077-85, http:// dx.doi.org/10.1007/s10661-012-2850-3

MOLOZZI, J., FRANÇA, J.S., ARAUJO, T.L.A., VIANA, T.H., HUGHES, R.M. \& CALLISTO, M. 2011. Diversidade de habitats físicos e sua relação com macroinvertebrados bentônicos em reservatórios urbanos em Minas Gerais. Iheringia, Ser. Zool. 101(3):191-199, http://dx.doi.org/10.1590/S0073-47212011000200006

McCORD, S.B., GUHA, G.S. \& GRIPPO, R.S. 2007. Effect of subsample size on seasonal and spatial comparisons of stream macroinvertebrate communities. Environ. Monit. Assess. 135:409422, http://dx.doi.org/10.1007/s10661-007-9660-z

PETKOVSKA, V. \& URBANIC, G. 2010. Effect of fixed fraction subsampling on macroinvertebrate bioassessment of rivers. Environ. Monit. Assess. 169:179-201, http://dx.doi.org/10.1007/ s10661-009-1161-9

ROCHA, L.G., MEDEIROS, E.S.F. \& ANDRADE, H.T.A. 2012. Influence of flow variability on macroinvertebrate assemblages in an intermittent stream of semi-arid Brazil. J. Arid Environ. 85:3340, http://dx.doi.org/10.1016/j.jaridenv.2012.04.001

ROSENBERG, D.M. 1998. A National Aquatic Ecosystem Health Program for Canada: We should go against the flow. Bull. Entomol. Soc. Am. 30:144-152.

SEBASTIEN, R.J., ROSENBERG, D.M. \& WIENS, A.P. 1988. A method for subsamplig unsorted benthic macroinvertebrates by weight. Hydrobiologia. 157:69-75, http://dx.doi.org/10.1007/ BF00008811

SHERIDAN, J.C. \& LYNDALL, G.S. 2001. SPSS: analysis without anguish. Versão 10.0 para windows. John Wiley \& Sons Austrália, Brisbane.

STENERT, C., MALTCHIK, L. \& ROCHA, O. 2012. Diversidade de invertebrados aquáticos em arrozais no Sul do Brasil. Neotrop. Biol. Cons. 7(1):67-77.

TRIVINHO-STRIXINO, S. 2011. Larvas de Chironomidae. Guia de identificação. Depto Hidrobiologia/Lab. Entomologia Aquática/ UFSCar, São Carlos.

WEBER, R.E. 1980. Functions of invertrebate hemoglobins with special reference to adaptations to environmental hypoxia. American Zoologist. 20:79-101.

WRONA, F.J., CULP, J.M. \& DAVIES, R.W. 1982. Macroinvertebrate subsampling: a simplified apparatus and approach. Can. J. Fish. Aquat. Sci. 39:1051-1054, http://dx.doi.org/10.1139/f82-140 